\title{
FOREIGN BANK PENETRATION AND THE DOMESTIC BANKING SYSTEM: EMPIRICAL EVIDENCE FROM TURKEY BASED ON THE VAR APPROACH
}

\author{
Derviş KIRIKKALELI \\ (Received: 29 March 2014; revision received: 8 May 2014; \\ accepted: 15 December 2014)
}

\begin{abstract}
I seek to investigate the relationship, if exits, between foreign bank penetration (FBP) and the determinants of bank performance, namely domestic bank assets (DB), domestic credit (CREDIT), and banking profitability (PRO) in Turkey using quarterly data from 1994Q1 to 2009Q4, while controlling for GDP and the event of the 2001 financial crisis. Using the Granger causality, impulse response function and variance decomposition, the short run dynamics are examined. The outcome of the Granger causality test indicates that there is unilateral causality, which runs from domestic bank assets to FBP at the 10\% level. Moreover, I also find feedback causality between FBP and CREDIT at the 5\% level. By employing impulse response functions, my findings reveal that rising foreign bank assets in Turkey tend to increase domestic bank assets and credit availability in short run, and vice versa. Surprisingly, no significant impact of FBP on profitability in the banking sector is observed.
\end{abstract}

Keywords: foreign bank penetration, VAR, time series modelling, domestic banking, Turkey

JEL classification indices: C22, F23, G21

Derviş Kirikkaleli, Chair at Department of Economics, Faculty of Business, Girne American University, Girne, T.R.N.C, Mersin-10-Turkey. E-mail: dervis_kirikkaleli@yahoo.com 


\section{INTRODUCTION}

The last two decades have brought many changes to the financial sector in the developing countries due mainly to the globalisation of the finance sectors. Alongside the globalisation process, foreign direct investment (FDI) and multinational bank activities have gradually risen. This process has motivated researchers to investigate foreign banks comprehensively. The share of foreign assets, on average, increased to almost $40 \%$ in 2005 from $22 \%$ in 1996. Moreover, total credit provided by foreign banks jumped to $26 \%$ of GDP in 2008 from $10 \%$ in 1996 .

Some researchers underlined the positive impact of foreign bank penetration (FBP) on capital ratio, efficiency and competition, credit availability, managerial skills, technology, and innovation capacity. However, others have taken into account the flip side of the coin by blaming FBP as a main reason behind the destabilisation of the domestic banking system. Empirical studies have revealed that the positive impact of FBP on the domestic banking system predominated (Cull - Peria 2010). Due to this, politicians in the world have encouraged foreign banks to take advantage of this since the beginning of the 1980s.

This study seeks to reveal the relationship between FBP and bank performance (namely, domestic bank assets, domestic credit, and bank profitability), while controlling for GDP and the event of the 2001 financial crisis.

The study is organised as follows. Section 2 provides an overview of the existing literature. Section 3 and 4 present the data and empirical methodology, Section 5 reports the empirical findings from the VAR models. Section 6 concludes.

\section{LITERATURE REVIEW}

At the beginning of the 1990s, the Turkish economy, especially the finance sector, was struggling with liquidity problems. In fact, Turkey in 1994 faced one of the most destructive crises in its modern history. In order to reduce uncertainty in the finance sector, the Turkish government started to provide a $100 \%$ insurance guarantee for deposits. Not surprisingly, the guarantee encouraged both public and private banks - including foreigners - in Turkey to take more risks, which was due mostly to borrowing with a high interest rate and lending with taking an open position. Then, the new banking law (No. 4389) was prepared and came into force to fix the problems of unhealthy banks in June 1999. According to the law, the criteria of establishing a bank, opening a branch, taking over a bank by the Savings Deposit Insurance Fund (SDIF), and cancelling the licence of a bank in Turkey were re-regulated. The law facilitated the possible sale or merger of unhealthy banks under the control of the SDIF (Denizer 1998). Therefore, six un- 
wholesome Turkish banks (Interbank, Egebank, Yurtbank, Sumerbank, Esbank, and Yasarbank) were taken over by the SDIF in 1999. The inefficient banking system triggered the banking crisis at the end of 2000 and as a solution, the exchange rate regime changed and a flexible exchange regime was implemented. The combined effect of these factors triggered the economic crisis in February 2001. Due to these reasons, foreign bank entries in Turkey had not been accelerated and the share of bank assets that were held by foreign banks in Turkey remained below $6 \%$ until the mid-2000s.

In order to rebuild the destroyed economy and the financial system as a result of the 2000 banking and 2001 economic crises, the Transition to the Strong Economy Program (TSEP) and the Restructuring Program for the Banking Sector (RPBS) were implemented. ${ }^{1}$ Moreover, the reforms were accelerated: for example a switch to a floating exchange rate from a pegged exchange rate granted greater central bank independence and the pursuit of a more credible monetary policy. The first sale of TMSF bank in the post-2001 crisis period was realised by the sale of Demirbank to HSBC bank for US\$ 350 million. After this sale, the perspective of European banks over SDIF banks changed positively (Bumin 2007).

Until the beginning of the 2000s, due to high systemic risk in Turkey, the share of foreign bank assets remained below $5 \%$ and the expected competitive banking system could not be achieved despite foreign bank entries in the 1980s. However, positive macroeconomic indicators, the achievement of political stability, the acceleration of reforms, especially in the finance sector (such as the switch to a floating exchange rate, granting greater central bank independence and the pursuit of a more credible monetary policy), the foundation of the Coordination Council and Investment Advisory Council, a new FDI law (No.6224), and the reduction in corporate tax led to a high growth rate in the banking sector in Turkey, except for the global crisis period ( $4^{\text {th }}$ quarter of 2008 and $1^{\text {st }}$ quarter of 2009). The ratio of the total bank assets in the banking sector to GNP increased from $67 \%$ in 2005 to $82 \%$ in 2009 . The share of bank assets held by the foreign banks jumped from US\$ 8.15 billion (3.50\% of the total banking assets) in 2005Q1 to

\footnotetext{
While the goals of TSEP were to accelerate the privatisation of unhealthy public companies and to achieve economic and financial stability via reconstructing trust and confidence in the market, RPBS aimed to restructure unhealthy banks and public banks, to prepare world-wide acceptable banking regulation and regulatory environment, and, finally, to strengthen private banking, whether domestic or foreign. During the reconstructing period, the penetration of foreign banks to the market was facilitated to benefit from the know-how, technology, managerial skills, and capital of foreign banks. Moreover, the capital structure of domestic public or private banks was strengthened based on the Basel II criteria and the sales of SDIF banks were accelerated (Bumin 2007).
} 
US\$ 84.24 billion (13.72\% of the total banking assets) in $2010 \mathrm{Q} 3,{ }^{2}$ although the total number of foreign banks fell to 17 . Moreover, the entry mode of foreign banks changed in the post-2001 period. In this period, they have mostly preferred the share acquisition of domestic banks as the entry mode rather than to open a branch or representation in the banking sector.

The negotiations on the integration of Turkey into the EU and the gradual rise of the share of banking assets to GNP have made Turkey a more interesting country to investigate and opened new debate on the banking sector.

Although the performance of foreign and domestic banks was meticulously investigated by Isik - Hassan (2002), Yildirim (2002), Demir et al. (2005), Ozkan-Gunay - Tektas (2006), Denizer et al. (2007), Aysan - Ceyhan (2008), and Fukuyama - Matousek (2011), the relationship, if exists, between banking performance and FBP has not been explored. Therefore, the objective of this paper is threefold: 1) to investigate the relationship between domestic bank assets and FBP; 2) to detect the relationship between domestic credit (DC) and FDP; and 3) to investigate the relationship between FBP and banking profitability.

Knickerbocker (1973) developed the "follow the leader" theory, combining it with the defensive FDI approach. According to his approach, in an oligopolistic market, the direct investment of a firm will encourage its rivals to invest in the same foreign market, because if the rivals do not follow the leader company which invests first into the foreign market - the rivals will lose their competitive stature in their home market. However, how FBP affects the behaviour of domestic banks in the host country and how rising (or falling) domestic assets in the bank system will affect the location choice of the foreign bank have not been explored in detail. Regarding domestic bank assets, only one study, Engwall et al. (2001), analyses the impact of the foreign bank assets on domestic bank assets in the Nordic countries: they found that rising (or falling) foreign bank assets were associated with higher (or lower) domestic bank assets in Norway, Sweden, and Finland. However, this hypothesis did not hold in Denmark. Otherwise, there is still a big question mark about the possible impact of domestic bank assets on FBP. In other words, the reaction of foreign banks when the domestic bank assets rise (or fall) has not been investigated in Turkey. This study also aims to fill this gap.

Credit availability has been used widely as a proxy for financial development in empirical papers. The majority of researchers agree that FBP to a host country is associated with better financial conditions, but this finding mostly indicates that foreign banks are less willing to lend to domestic companies, especially

2 These ratios are calculated by the author using data from The Bank Association of Turkey and the Central Bank of the Republic of Turkey. 
small ones, than domestic banks do. This may arise due to the lack of information and difficulty and cost to gather information about small companies in the host markets.

Although some studies (Bleger - Rozenwurcel 2000; Goldberg et al. 2000; Berger et al. 2001; Satta 2004; Clarke et al. 2005; Clarke 2006; Main 2006; Detragiache et al. 2008) compare the credit provision of domestic and overseas banks to the domestic market in a specific country or group of countries, the dynamic relationship between FBP and credit availability has remained unexplored. The findings of Berger et al. (2001) reveal that small companies in Argentina have a lesser chance of getting credit from foreign and large banks relative to large companies. Moreover, Mian (2006) finds that foreign banks in Pakistan are less willing to lend to opaque businesses relative to domestic banks. The findings of Bleger - Rozenwurcel (2000) show that between 1996 and 1998, FBP led to the reduction of bank credits to small enterprises to $16 \%$ from $20 \%$ in Argentina. By analysing banking sectors in Mexico and Argentina, Goldberg et al. (2000) find that the loan growth of overseas banks was much more than that of domestic banks in these countries. Furthermore, the overseas banks contributed positively to both the volatility of lending and credit. They also point out that the credit growth of foreign banks in these countries did not change dramatically throughout the domestic crises at the end of the 1990s.

Clarke (2006) investigates the effect of FBP on domestic market credit availability using the surveying technique in 38 transition and developing countries. He points out that domestic credit is positively affected by FBP. However, his findings also indicated that the contribution of foreign banks to credit provision for small and medium companies is less than that of domestic banks. Cross-country level evidence of Detragiache et al. (2008) also supports the idea that FBP is associated with less credit provision. This evidence is based on 89 low-income countries for the period of 1999-2002.

A different finding regarding this issue comes from Clarke et al. (2005), who conclude that large foreign banks in Chile and Colombia lent more to small- and medium-sized enterprises than domestic banks. Moreover, medium and large foreign banks in Argentina and Chile achieved higher growth of lending to small enterprises relative to medium and large domestic banks during the period of 1997-2000. In most cases, the evidence indicates that foreign banks are less willing to lend to domestic companies, especially small ones, than domestic banks. This may arise due to lack of information, the difficulty and cost of gathering information about small companies, and because of different economic, financial, political, and social factors among countries.

In line with both empirical and theoretical research, profitability in a host country is a main driving factor of foreign banks. Claessens et al. (2001) investigate 
the impact of FBP on domestic banks using almost 8000 banks from 80 countries for the period of 1988-1995. They find that foreign banks tend to run businesses more profitably relative to domestic banks and the rise of foreign banks in these markets tends to reduce the host banking sector's profitability. Denizer (2000) examines the effect of foreign banks on the banking sector in Turkey using annual data sets from 1980 to 1997 . His findings reveal that FBP is inversely related to the return on assets. Zajc (2004) examines the effect of overseas banks on the performance of domestic banks in six European transition countries. His findings indicate that overseas banks tend to reduce profitability and raise the cost of indigenous banks.

Lensink - Hermes (2004) build on the study of Claessens (2001). They find that FBP does not have a strong impact on the domestic profitability at lower levels of economic development. Furthermore, at higher levels of economic development of the host countries, the impacts are not clear because FBP is either associated with falling profitability in the banking sector or not associated with any change in profitability.

Apart from the impact of FBP on the host country, Facarelli - Pozzolo (2000) and Bumin (2007) investigate the possible effects of profitability on foreign banks by examining the factors influencing the location choice of overseas banks. The empirical result of Facarelli - Pozzolo (2000)'s paper using 260 banks' data from OECD countries indicates that profitability resulting from an expected growth is one of the main factors influencing the location choice of foreign banks, especially for subsidiaries. Moreover, integration between the host and home markets plays a role in the decision of foreign banks. Bumin (2007) tries to identify the key factors determining foreign banks in Turkey using data from January 2003 to June 2006. His findings indicate that profitability in the banking sector is the main factor influencing foreign banks. Furthermore, economic growth, potential demand for banking services are the other determinants of foreign banks in Turkey. However, none of these papers investigated two-way linkages between FBP and profitability using the same data set. I aim to fill this gap for Turkey by investigating the relationship between profitability and FBP.

Although numerous papers investigated either the determinant or impact of FBP in developed or developing markets, the two-way linkage between FBP and the banking variables used the same data set. Therefore, this paper is likely to open new debate on this subject, not only in the Turkish banking system. 


\section{DATA}

The time series variables used in the empirical tests of this paper consist of quarterly data for the period 1994Q1 to 2009Q4 (64 observations). The time series variables used in the models are shown below: ${ }^{3}$

FBP: Total assets held by foreign banks in the banking sector. Holding a 50\% share acquisition by a foreign bank or foreign investor in a host country is regarded as a minimum requirement for having an important influence on the management of the acquired bank in Turkey. In other words, after acquiring 50\% or more shares, a domestic bank is recorded as a foreign bank in most of the countries.

PRO: Return on assets in the banking sector was used as a proxy for profitability in the banking sector. The raw data were used because some observations for the variable are negative.

CREDIT: Total domestic credit provided by banks in Turkey. The variable was also expressed in its logarithmic transformation.

DB: Total assets in the banking sector, excluding the foreign ones. The variable was expressed in its logarithmic transformation.

GDP: The level of nominal GDP is used as a control variable since it is believed that GDP is an important determinant of FDI, FBP and FPI. The findings of Buch (2000), Brealey - Kaplanis (1996) and Yamori (1998) underlined that GDP in host countries seems to be the most important factor that affects the location decision of multinational banks.

DUM2001: This is used as a control variable since it is believed that the financial crisis in 2001 led to significant changes in the Turkish banking sector.

Descriptive statistics for FBP, PRO, CREDIT, and DB variables are demonstrated in Table 1.

The FBP variable shows variation, ranging from 7.36 to 11.28. Moreover, there is also variation in the DB, CREDIT, and PRO variables, ranging from 10.74 to 13.05, from 9.76 to 12.40 , and from -3.25 to 5.02 , respectively. Table 1 also

The figures of total assets of foreign banks, total credit, total assets, and return on assets in the banking sector are not presented in the paper. However, the author will provide these upon request. 
Table 1. Descriptive statistics for the variables of FBP, PRO, CREDIT and DB

\begin{tabular}{lrrrr}
\hline & \multicolumn{1}{c}{ FBP } & \multicolumn{1}{c}{ PRO } & CREDIT & \multicolumn{1}{c}{ DB } \\
\hline Mean & 8.900 & 1.191 & 10.769 & 11.852 \\
Median & 8.600 & 1.298 & 10.479 & 11.741 \\
Maximum & 11.280 & 5.023 & 12.401 & 13.049 \\
Minimum & 7.357 & -3.249 & 9.755 & 10.739 \\
Std. Dev. & 1.212 & 1.572 & 0.774 & 0.671 \\
Skewness & 0.797 & -0.831 & 0.868 & 0.294 \\
Kurtosis & 2.427 & 4.309 & 2.379 & 1.926 \\
Jarque-Bera & 8.266 & 12.881 & 9.788 & 4.307 \\
Probability & 0.016 & 0.001 & 0.007 & 0.116 \\
Sum & 614.115 & 82.247 & 743.126 & 817.808 \\
Sum Sq. Dev. & 99.936 & 168.043 & 40.800 & 30.690 \\
Observations & 64 & 64 & 64 & 64 \\
\hline
\end{tabular}

Note: The data is based on 64 observations (1994Q1-2009Q4).

Source: The Central Bank of the Republic of Turkey and The Bank Association of Turkey.

provides information about the distribution of the variables by using skewness, kurtosis, and the Jarque-Bera test. Whereas FBP, CREDIT, and DB variables are positively skewed, the PRO variable is negatively skewed. Regarding kurtosis, the distribution of FBP, CREDIT, and DB variables has large tails (more peaked), while the distribution of the PRO variable has small tails (flatter). In addition, the result of the Jarque-Bera test reveals that the distribution of FBP, CREDIT variables, and PRO variables is normal, but the null hypothesis that DB has a normal distribution cannot be rejected with a $\chi^{2}=4.307(p$-value $=0.116)$.

\section{METHODOLOGY}

We tested the short run dynamics between FBP and the determinants of bank performance (namely, total bank assets, domestic credit, and banking profitability), while controlling for GDP and the 2001 financial crisis. The first step is to determine whether or not the variables have a unit root. The early paper of Dickey Fuller (1979, ADF) investigated how to test unit root in the time series variables. Then, Phillips - Perron (1988) developed another unit root test (PP unit root test). The main difference between the ADF and PP tests arises in a case of heteroskedasticity and serial correlation. The results of these tests may be significantly different because of different ways to correct serial correlation when the sample size is finite. Moreover, the PP and ADF tests have low power when AR root is close to 1 (Cochrane 1991). Thus, the alternative hypothesis could not accept 
when the sample size is small (DeJong et al. 1992). In addition, when trend adds to the regression in these unit root tests, the power of such tests reduces, therefore including only the constant in the regression has more power than a test that includes both an intercept and a trend. The conventional PP and ADF tests are still the most popular unit root tests in macroeconomic and financial modelling despite these weaknesses of such tests. However, as suggested by Zivot - Wang (2005), to overcome these problems, more efficient unit root tests - Ng-Perron (2001) and ERS point optimal (1996) - were used to detect whether the banking variables have unit root, in other words, whether they are non-stationary.

The PP test of Perron - Ng $(1996,2001)$ uses the GLS detrending procedure of ERS. The unit root test is constructed by four test statistics, which are $\mathrm{MZ}_{\alpha}$, MZt, MSB, and MPT. In my models, only the $\mathrm{MZ}_{\alpha}$ test statistic was employed and its results are shown in Table 2. The $\mathrm{MZ}_{\alpha}$ test statistic is defined as; $\mathrm{MZ}_{\alpha}=$ $\left(\mathrm{T}^{-1}\left(y_{t}^{d}\right)^{2}-f_{0}\right) /\left(2_{\mathrm{K}}\right)$ where $\mathrm{K}=\frac{\sum_{t}^{T}=2\left(y_{t}^{d}-1\right)^{2}}{T^{2}}$, the statistic $\mathrm{MZ}_{\alpha}$ is a more effective version of $Z_{\alpha}$ of the PP in terms of size and power.

Another unit root test that is used in this paper is the ERS point optimum. The latter was developed by Elliott et al. (1996), and is based on the quasi-differencing regression, which is defined as: $d\left(v_{t} \mid a\right)=d\left(z_{t} \mid a\right)^{\prime} \beta(a)+e_{t}$; where $d\left(v_{t} \mid a\right)$ and $d\left(z_{t} \mid a\right)$ are quasi-differenced data for $v_{t}$ and $z_{t}$, respectively. Moreover, $e_{t}$ is the residual term and $\beta$ (a) is the coefficient to be estimated in the quasi-differencing regression. While the null hypothesis tested is $\alpha=1$, the alternative hypothesis tested is $\alpha=\bar{a}$ where $\bar{a}=1-7 / T$ when $z_{t}$ contains only a constant, and $\bar{a}=1-13.5 / T$ when $z_{t}$ contains both a constant and a trend. The test statistics in the ERS point optimum to test Ho is defined as; $\mathrm{P}_{\mathrm{T}}=(\operatorname{SSR}(\overline{\mathrm{a}})-(\overline{\mathrm{a}}) \mathrm{SSR}(1)) / f_{\mathrm{o}}$ where $f_{\mathrm{o}}$, at frequency zero, is an estimator for the error spectrum.

It is well-known that the lag length specification is another important issue for macroeconometric and financial modelling. In the literature, there is no criterion that gives perfectly consistent result better than others. Schwarz (SC) and Akaike (AIC) information criteria are widely used information criteria in macroeconometric and financial modelling. To select the optimal lag for my models, the VAR Lag Order Selection Criteria were applied to determine specific lag for the models. SC, AIC, Hannan-Quinn (HQ) information criteria, final prediction error (FPE), and sequential modified LR test statistics (LR) were employed to select the optimal lag. It is no surprise to have multiple optimal lags for the models using 5 different information criteria. My decision is based on the most appropriate optimal lag for the VAR models where there is no autocorrelation, no serial correlation, and no heteroskedasticity. Therefore, different lags for the VAR models are selected based on different information criteria for the models with and without the control variables. 
Next, I employed the VAR-based Granger causality test, which is also called the block exogeneity Wald test, to investigate causal relationship in the short run between FBP and the determinants of bank performance, namely DB, CREDIT, and PRO. The Granger causality is a test to determine (i) whether $\mathrm{X}$ variable Granger causes the $\mathrm{Y}$ variable and (ii) whether $\mathrm{Y}$ variable Granger causes the $\mathrm{X}$ variable. If the $\mathrm{Y}$ variable does not cause $\mathrm{X}$, the parameters of $\mathrm{X}$ on the lagged $\mathrm{Y}$ are jointly zeros (Granger 1969). The general equation of the VAR-based Granger causality test for my models - which are with the control variables - are shown below:

eq.(1);

$$
F B P_{t}=\beta_{1}+\sum_{i=1}^{n} \alpha_{1} D B_{t-i}+\sum_{i=1}^{n} \mu_{1} F B P_{t-i}+\sum_{i=1}^{n} \infty_{1} G D P_{t-i}+\sum_{i=1}^{n} \rho_{1} D U M 2001_{t-i}+e_{t}
$$

eq.(2);

$$
D B_{t}=\beta_{2}+\sum_{i=1}^{n} \alpha_{2} D B_{t-i}+\sum_{i=1}^{n} \mu_{2} F B P_{t-i}+\sum_{i=1}^{n} \infty_{2} G D P_{t-i}+\sum_{i=1}^{n} \rho_{2} D U M 2001_{t-i}+e_{t}
$$

eq.(3);

$$
F B P_{t}=\beta_{3}+\sum_{i=1}^{n} \alpha_{3} D B_{t-i}+\sum_{i=1}^{n} \mu_{2} F B P_{t-i}+\sum_{i=1}^{n} \infty_{2} G D P_{t-i}+\sum_{i=1}^{n} \rho_{2} D U M 2001_{t-i}+e_{t}
$$

eq.(4);

$$
\begin{gathered}
C R E D I T_{t}=\beta_{4}+\sum_{i=1}^{n} \alpha_{4} \operatorname{CREDIT}_{t-i}+\sum_{i=1}^{n} \mu_{4} F B P_{t-i}+\sum_{i=1}^{n} \infty_{4} G D P_{t-i}+ \\
\sum \rho_{4} D U M 2001_{t-i}+e_{t}
\end{gathered}
$$

eq.(5);

$$
F B P_{t}=\beta_{5}+\sum_{i=1}^{n} \alpha_{5} P R O_{t-i}+\sum_{i=1}^{n} \mu_{5} F B P_{t-i}+\sum_{i=1}^{n} \infty_{5} G D P_{t-i}+\sum_{i=1}^{n} \rho_{5} D U M 2001_{t-i}+e_{t}
$$

eq.(6);

$$
P R O_{t}=\beta_{6}+\sum_{i=1}^{n} \alpha_{6} P R O_{t-i}+\sum_{i=1}^{n} \mu_{6} F B P_{t-i}+\sum_{i=1}^{n} \infty_{6} G D P_{t-i}+\sum_{i=1}^{n} \rho_{6} D U M 2001_{t-i}+e_{t}
$$

where $\mathrm{n}$ denotes the numbers of lag which were determined by the information criterions, $\beta_{1-6,}, \alpha_{1-6}, \infty_{1-6}$ and $\rho_{1-6}$ are parameters for estimation, and $e_{t}$ and $u_{t}$ are residual terms.

I detect whether there is causal relationship among the variables using the VAR Granger causality technique. The only criteria to perform VAR Granger 
causality test are to have stationary variables because if the time series variables have unit root, the Wald $\left(\chi^{2}\right)$ test statistic will be worthless and VAR stability will not meet. Therefore, in the VAR models, the first differences of the FBP, DB, CREDIT, and GDP variables were used, whereas the level of the PRO variable was used. Moreover, the sign of relationship among the variables and how long these impacts will remain effective or change over time cannot be investigated by the outcomes of the Granger causality test. Therefore, to get information about this, I also performed the generalised impulse response function and variance decomposition as suggested by Koop et al. (1996) and Pesaran - Shin (1998).

The conventional impulse response (Sims 1980) is heavily criticised due to the orthogonality assumption. The conventional impulse response, which is based on the Choleski factorisation of vector autoregression, is sensitive to variable order. The developed version of the impulse response function, called "generalised impulse response function" in the system, is indifferent of the ordering of the variable. The effect of the $\mathrm{X}$ variable on the $\mathrm{Y}$ variable or the effect of changing the $\mathrm{X}$ variable on the $\mathrm{Y}$ variable can be evaluated over specific time by the impulse response function (Hill et al. 2008). In other words, the magnitude of the effect of the innovation is investigated by the outcome of the impulse response technique (Pesaran - Shin 1998). In all models, the impulse response at the 5\% level was accepted as significant at a point where both the confidence bands are above or below the horizontal line. Since the aim of this paper is to investigate the relationship between FBP and the determinants of bank performance, response to a shock to the $\mathrm{X}$ variable by the $\mathrm{X}$ variable was not investigated.

Apart from the impulse response function, I applied the variance decomposition technique to obtain information about the percentage of the movement in the endogenous variables that, because of their own innovations, are against innovations to the other variables. In other words, the technique was performed to test the exogeneity of the variables. Using the Monte Carlo simulation with 1,000 replications, the lower and upper error bounds in the variance decompositions were calculated in the models.

\section{EMPIRICAL FINDINGS}

Before performing VAR models, the stationarity of time series variables is detected by the Ng-Perron (2001) and ERS Point Optimal (Elliott et al. 1996) unit root tests. The results regarding the outcome of the unit root tests are presented in Table 2. These tests are performed to find out the order of integration for the FBP, PRO, CREDIT, and DB variables. For the first variable - FBP -, integration of order zero I ( 0 ) is not found because the calculated Ng-Perron $\mathrm{MZ}_{\alpha}$ test statistics, 
which are 1.773 (the model with an intercept) and -2.392 (the model with a trend and an intercept), are greater than the $5 \%$ critical values of -8.10 (the model with an intercept) and -17.30 (the model with a trend and an intercept), respectively. The results of the ERS point optimum test are in line with the results of the $\mathrm{Ng}$ Perron in terms of FBP in both cases: (1) the model with an intercept and (2) the model with an intercept and a trend. Therefore, the variable has unit root at the integration of zero order. In other words, the variable has a higher integration order. At the first difference, I (1) of FBP, all test statistics (the model with an intercept and the model with a trend and an intercept) are less than its critical values at the $1 \%$ and $5 \%$ levels. Thus, the null hypothesis cannot be rejected and the variable is integrated of order 1 . Regarding DB and CREDIT variables, Table 2 indicates that the variables are integrated of order 1 . This is literal because of the behaviours and trends of these variables. ${ }^{4}$ The time series data of DB, CREDIT, and FBP wander around a trend and this is one of the main indicators of nonstationary time series. This is due to using the accumulated foreign bank assets, accumulated domestic bank assets, and total domestic credit. With respect to the PRO variable, the result is complex, because although the calculated Ng-Perron test statistic (the model with an intercept) and the calculated ERS-Point Optimal test statistics (the model with an intercept and the model with a trend and an intercept) indicate that the variable has unit root, the calculated Ng-Perron test statistic (the model with an intercept) is -3.968 , which is greater than the $5 \%$ critical values of -8.10 . However, I accepted the PRO variable as stationary after examining its trend over time since the time series data of PRO clearly fluctuates around an intercept. ${ }^{5}$ Consequently, whilst FBP, DB, and CREDIT variables were I (1), the PRO variable was accepted I (0). It is worthy to mention that the findings in $\mathrm{MZ}_{\alpha}$ are in line with the other test statistics of Ng-Perron (2001). Therefore, in the VAR models, the first differences of FBP, DB, and CREDIT variables were used while the level of PRO was performed.

This paper employed the VAR-based Granger causality test to investigate the short-run causal relationships between FBP and banking variables, while controlling for GDP and the 2001 financial crisis. The results regarding short-run causal relationships presented in Table 3 are based on chi-square tests (the model with and without the control variables). In the first model, I test whether FBP Granger cause DB and (ii) whether DB Granger cause FBP. The null hypothesis that FBP does not Granger cause DB cannot be rejected with a $\chi^{2}=0.933$ (p-value $=$

4 The nature of time series data treats as a non-stationary time series because of trending, wandering around an intercept, and wandering around a trend.

5 The fluctuation of time series data around a trend or an intercept reflects the stationarity of time series. 
Table 2. Unit Root Test for the variables of FBP, PRO, CREDIT and DB

\begin{tabular}{lcccc}
\hline & \multicolumn{2}{c}{ Ng-Perron $\left(\mathrm{MZ}_{\alpha}\right)^{\mathrm{a}}$} & \multicolumn{2}{c}{ ERS Point Optimal $^{\mathrm{b}}$} \\
& $\mathrm{C}$ & $\mathrm{C} \mathrm{\&} \mathrm{T}$ & $\mathrm{C}$ & $\mathrm{C} \& \mathrm{~T}$ \\
\hline FBP & 1.773 & -2.392 & 81.944 & 38.850 \\
DFBP & $-22.880^{* *}$ & $-33.478^{* *}$ & $0.747^{* *}$ & $2.685^{* *}$ \\
& & & & \\
PRO & -3.968 & $-24.825^{* *}$ & $1.533^{* *}$ & $3.739^{* *}$ \\
DPRO & $\mathrm{N} . \mathrm{A}$ & $\mathrm{N} . \mathrm{A}$ & $\mathrm{N} . \mathrm{A}$. & $\mathrm{N} . \mathrm{A}$. \\
& & & & \\
CREDIT & 0.713 & -4.314 & 29.876 & 25.459 \\
DCREDIT & $-28.157^{* *}$ & $-28.889^{* *}$ & $0.882^{* *}$ & $3.244^{* *}$ \\
& & & & \\
DB & 1.827 & 5.377 & 143.11 & 20.113 \\
DDB & $-31.526^{* *}$ & $-31.940^{* *}$ & $0.814^{* *}$ & $2.913^{* *}$ \\
\hline
\end{tabular}

Notes: $\mathrm{C}$ and C\&T denote constant and constant and trend, respectively. D initial letter denotes the first difference of the time series variables. The integration order for the logged GDP is one using the unit root tests. The finding regarding GDP is not shown in Table 2 because the paper only investigates the relationship between the banking variables and FBP. The variable is used as a control variable.

\footnotetext{
**, *, and ${ }^{\mathrm{y}}$ statistically significant at the $0.01,0.05$, and 0.10 levels, respectively.

a including only constant, one-sided test of the HO model that the variable has unit root; critical values are equal to $-5.70,-8.10$, and -13.80 at the $10 \%, 5 \%$, and $1 \%$ levels, respectively.

a including a constant and a trend, one-sided test of the HO model that the variable has unit root; critical values are equal to $-14.20,-17.30$, and -23.80 at the $10 \%, 5 \%$, and $1 \%$ levels, respectively.

b including only constant, one-sided test of the $\mathrm{HO}$ model that the variable has unit root; critical values are equal to, $4.008,3.023,1.900$ at the $10 \%, 5 \%$, and $1 \%$ levels, respectively.

$\mathrm{b}$ including a constant and a trend, one-sided test of the HO model that the variable has unit root; critical values are equal to $6.777,5.689,4.235$ at the $10 \%, 5 \%$, and $1 \%$ levels, respectively.
}

0.333). ${ }^{6}$ This implies that changes in FBP do not significantly lead to changes in domestic bank assets. This is probably due to the dominancy of domestic banks in the banking sector in Turkey. The share of foreign bank assets in the banking sector has not exceeded 18\%. Therefore, the dominancy of domestic banks in the banking sector is likely to minimise any reaction of them against FBP to the market. Moreover, the result of the first model in Table 3 also shows that DB Granger cause FBP at the $10 \%$ level with a $\chi^{2}=3.068(\mathrm{p}$-value $=0.079$ ). The results also suggest that at the $10 \%$ level there is unilateral causality which runs from DB to FBP. Without the control variables, there is Granger causality from DB to FBP even at the $5 \%$ level in model 1 . This implies that the changes in domestic bank

6 The optimal lag length - lag (1) - of the first model (the model with the control variables) was determined by LR, FPE, and AIC information criteria because the optimal lag length of other information criteria led to serial correlation and/or autocorrelation. For the second and third models, the same procedures were followed to determine the optimal lag length for the VAR models. 
assets significantly lead to changes in FBP. As expected, the reaction of foreign banks against possible changes in a host country is more certain and quicker than that of domestic banks.

Table 3 shows the existence of causality from CREDIT to FBP with a $\chi^{2}=$ 11.696 and from FBP to CREDIT with a $\chi^{2}=5.562^{7}$. Thus, there is bilateral or feedback causality between CREDIT and FBP at the 5\% level. The findings in model 2 with the control variables are consistent with model 2 without the control variables. In other words, FBP leads to change in domestic credit availability, and vice versa. The presence of bilateral causality in the second model among the variables is not surprising because foreign banks contribute to the credit availability of host countries either directly by providing credits to the domestic sectors, or indirectly by affecting the credit availability of domestic banks to the domestic market. Credit availability in a market indicates the financial development of a country, which is one of the main factors that affect the decision of foreign banks while selecting a host country to invest in. Thus, the change in financial development in Turkey leads to a change in foreign penetration to the banking sector.

As seen in Table 3, although there was a significant Granger causality from PRO to FBP at the $10 \%$ level, adding control variables to model 3 eliminated this significant causality. However, it is not surprising to detect no causal relationship between PRO and FBP at the 5\% level in Turkey. The lack of causality from FBP to banking profitability is not consistent with pervious empirical findings. This is because rising foreign bank assets in Turkey were not associated with a higher number of banks.

However, the results of the Granger causality test cannot answer the questions of the sign of relationship in all models and how long possible impacts will remain effective or change over time. To answer these questions for my models, I apply the generalised impulse function and variance decomposition techniques, controlling for GDP and periodic dummy (DUM2001) variables. Figures 1 to 6 report the response of banking variables to a shock to the FBP, and vice versa. ${ }^{8}$ Since the aim of this paper is to investigate the relationship between FBP and banking variables, the response to a shock to the $\mathrm{X}$ variable by the $\mathrm{X}$ variable was not investigated. Moreover, the findings between banking variables and control variables, and the findings between FBP and control variables are not presented.

7 In the second model (the model with the control variables), all information criteria gave the same optimal lag length, which is lag (2). It is worth mentioning that this estimates the joint effects of $\mathrm{FBP}_{\mathrm{t}-1}$ and $\mathrm{FBP}_{\mathrm{t}-2}$ on CREDIT.

8 The results from the models without control variables regarding the generalised impulse response functions are presented in Figures 7-12. 
Table 3. VAR-based Granger causality (block exogeneity Wald test)

\begin{tabular}{|c|c|c|c|c|c|c|c|c|}
\hline \multicolumn{9}{|c|}{ The models with the control variables } \\
\hline & \multirow{2}{*}{$\begin{array}{l}\text { Independent } \\
\text { variable }\end{array}$} & \multirow{2}{*}{$\begin{array}{l}\text { Granger } \\
\text { cause }\end{array}$} & \multirow{2}{*}{$\begin{array}{l}\text { Dependent } \\
\text { variable }\end{array}$} & \multirow[t]{2}{*}{ DoF } & \multirow[t]{2}{*}{$\chi^{2}$} & \multirow[t]{2}{*}{ P-value } & \multicolumn{2}{|c|}{ Decision } \\
\hline & & & & & & & $5 \%$ level & $10 \%$ level \\
\hline \multirow[t]{2}{*}{ Model 1} & DB & $\rightarrow$ & FBP & 1 & 3.069 & 0.079 & $\mathrm{X}$ & $\sqrt{ }$ \\
\hline & FBP & $\rightarrow$ & DB & 1 & 0.933 & 0.333 & $\mathrm{X}$ & $\mathrm{X}$ \\
\hline \multirow[t]{2}{*}{ Model 2} & CREDIT & $\rightarrow$ & FBP & 2 & 11.696 & 0.003 & $\sqrt{ }$ & $\sqrt{ }$ \\
\hline & FBP & $\rightarrow$ & CREDIT & 2 & 5.562 & 0.047 & $\sqrt{ }$ & $\sqrt{ }$ \\
\hline \multirow[t]{5}{*}{ Model 3} & PRO & $\rightarrow$ & FBP & 2 & 2.814 & 0.244 & $\mathrm{X}$ & $\mathrm{X}$ \\
\hline & FBP & $\rightarrow$ & PRO & 2 & 1.873 & 0.391 & $\mathrm{X}$ & $\mathrm{X}$ \\
\hline & \multicolumn{8}{|c|}{ The models without the control variables } \\
\hline & \multirow{2}{*}{$\begin{array}{l}\text { Independent } \\
\text { variable }\end{array}$} & \multirow{2}{*}{$\begin{array}{l}\text { Granger } \\
\text { cause }\end{array}$} & \multirow{2}{*}{$\begin{array}{l}\text { Dependent } \\
\text { variable }\end{array}$} & \multirow[t]{2}{*}{ DoF } & \multirow[t]{2}{*}{$\chi^{2}$} & \multirow[t]{2}{*}{ P-value } & \multicolumn{2}{|c|}{ Decision } \\
\hline & & & & & & & $5 \%$ level & $10 \%$ level \\
\hline \multirow[t]{2}{*}{ Model 1} & DB & $\rightarrow$ & FBP & 3 & 13.767 & 0.003 & $\sqrt{ }$ & $\sqrt{ }$ \\
\hline & FBP & $\rightarrow$ & DB & 3 & 1.1474 & 0.688 & $\mathrm{X}$ & $\mathrm{X}$ \\
\hline \multirow[t]{2}{*}{ Model 2} & CREDIT & $\rightarrow$ & FBP & 2 & 11.849 & 0.002 & $\sqrt{ }$ & $\sqrt{ }$ \\
\hline & FBP & $\rightarrow$ & CREDIT & 2 & 6.312 & 0.042 & $\sqrt{ }$ & $\sqrt{ }$ \\
\hline \multirow[t]{2}{*}{ Model 3} & PRO & $\rightarrow$ & FBP & 1 & 3.465 & 0.062 & $\mathrm{X}$ & $\sqrt{ }$ \\
\hline & FBP & $\rightarrow$ & PRO & 1 & 0.422 & 0.515 & X & X \\
\hline
\end{tabular}

Note: $\rightarrow$ indicates the direction of Granger causality while DoF and $\chi 2$ denote the degree of freedom and chisquare, respectively. The first differences of FBP, DB, and CREDIT variables were used while the level of PRO was performed. Since the aim of this paper is to investigate the relationship between FBP and banking variables (namely DB, CREDIT and PRO), the possible causal impacts of control variables on the banking variables and FBP are not presented in Table 3.

As seen in Figures 1-6, the findings from the generalised impulse response functions are similar in the model with and without the control variables, and therefore the explanations are based on the models with the control variables.

Using a twelve-quarter period, the study also investigated the likely effects of shocks to the variables within twelve quarters. Figure 1 illustrates that response to initial shock to DB by FBP is positive and significant, but the effect of shocks dies away after the $1^{\text {st }}$ period. Thus, in Turkey, rising domestic bank assets contribute to FBP in the short run.

Figure 2 shows that the reverse line is initially significant and positive. Therefore, rising FBP leads to an increase of domestic bank assets. This is rational and in line with the finding of Engwall et al. (2001). However, the significant shock dies away after the $1^{\text {st }}$ period, although the response is also significant and positive 


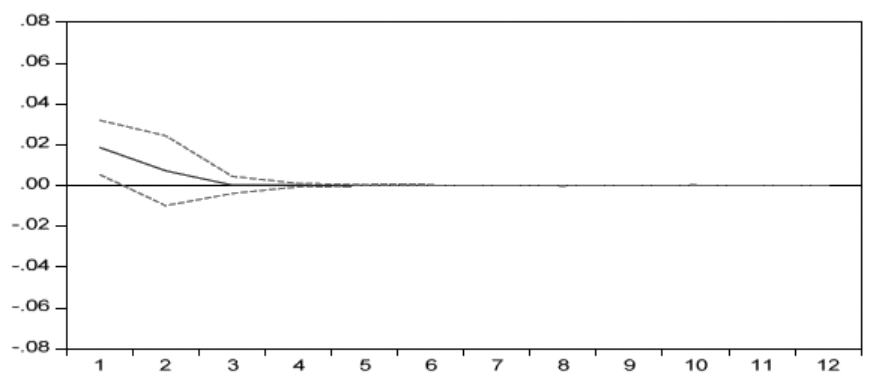

Figure 1: Response of $\mathrm{DB}$ to FBP

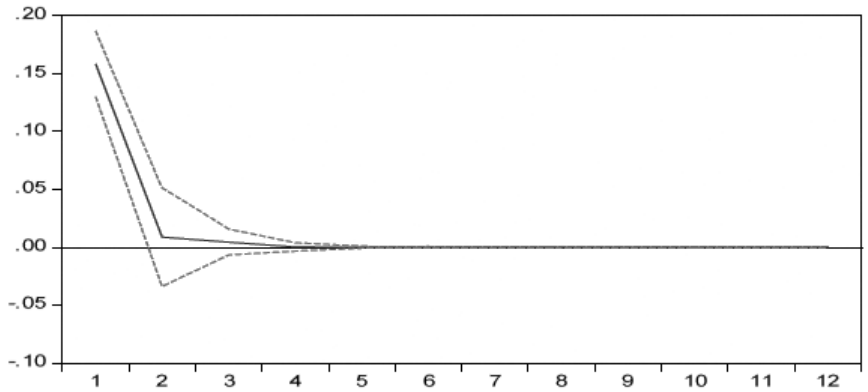

Figure 2: Response of FBP to DB

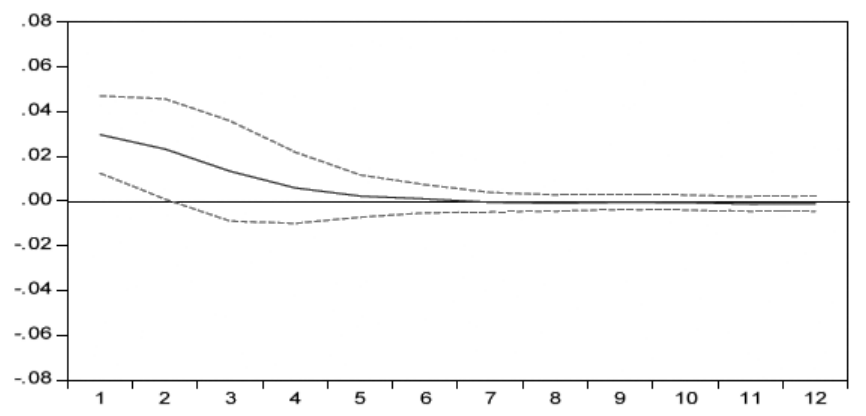

Figure 3: Response of CREDIT to FBP

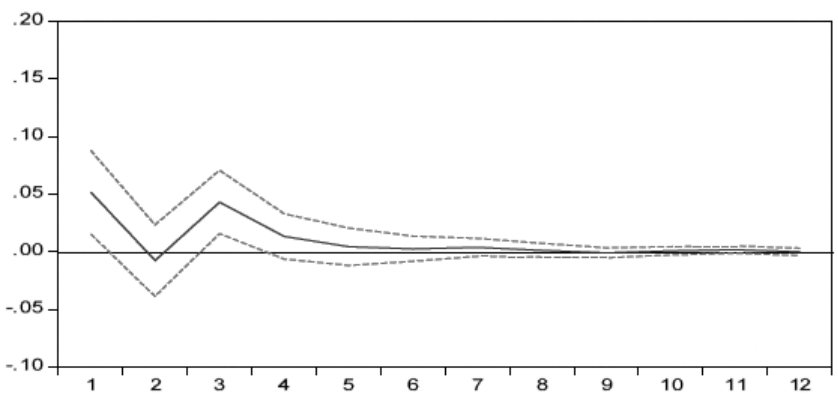

Figure 4: Response of FBP to CREDIT 

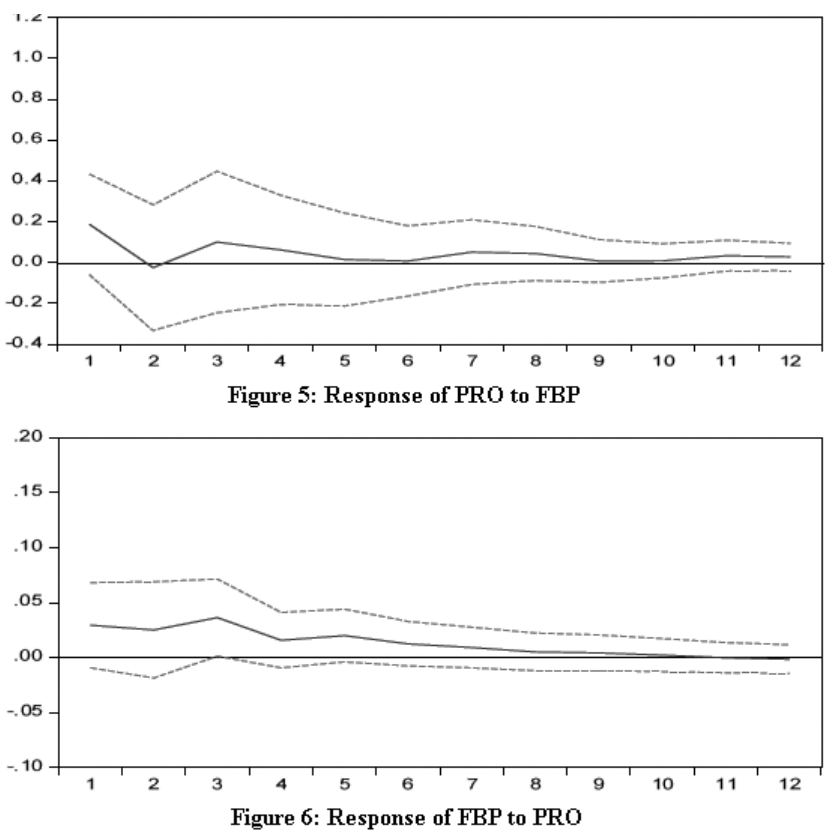

Figures 1-6. Response to generalised One S.D. Innovations \pm 2 S.E.

(The models with the control variables)

at the $2^{\text {nd }}$ and $4^{\text {th }}$ periods in the model without the control variables. ${ }^{9}$ The empirical finding can be supported by an example. First, whenever foreign banks invest in a host country, domestic banks are likely to revise their investment strategies and they are likely to invest in their home market, rather than abroad, to keep their share in the banking sector as high as possible in order to be competitive against the foreign banks. Second, foreign banks that invest in a host country are likely to have technological and managerial advantages relative to the domestic banks. FBP, thus, is likely to force the domestic banks to invest in R\&D. If the domestic banks do not improve their technological capacity or managerial skills, they can lose their competitive edge against the foreigners in the banking sector. As is well known, domestic banks mostly invest in R\&D in the home market to improve or innovate products rather than in the foreign market. Therefore, FBP in the banking sector tends to increase the investment of domestic banks.

9 The results with and without the control variables in this model reveal that adding control variables led to the disappearance of the significant responses in the $2^{\text {nd }}$ and $4^{\text {th }}$ periods. This situation appears probably because of the importance of the control variables on the FBP variable. 


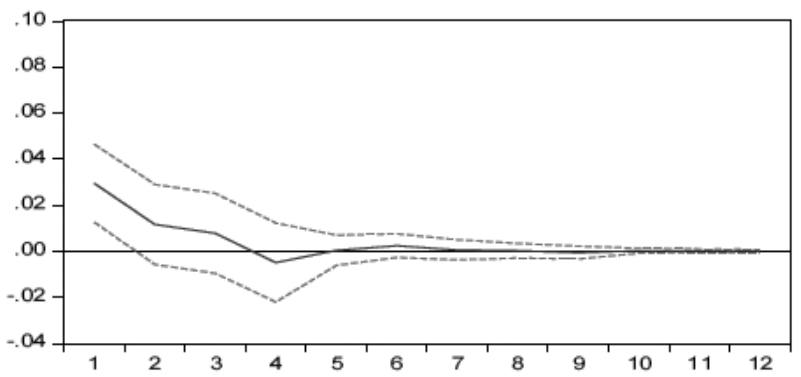

Figure 7: Response of DB to FBP

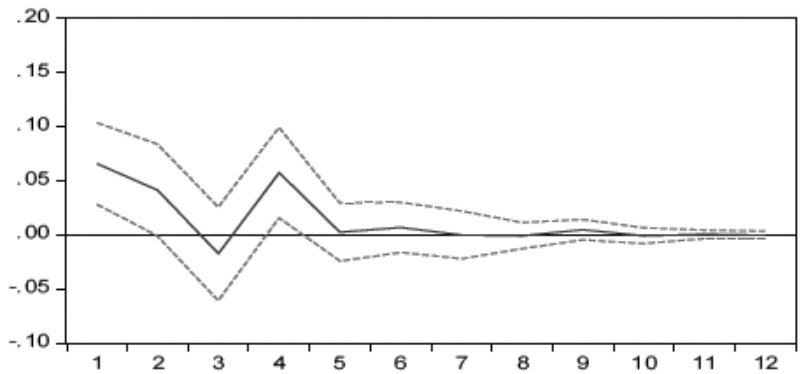

Figure 8: Response of FBP to DB

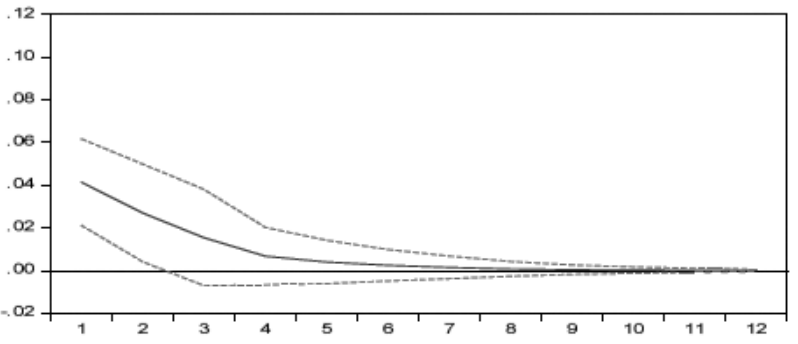

Figure 9: Response of CREDIT to FBP

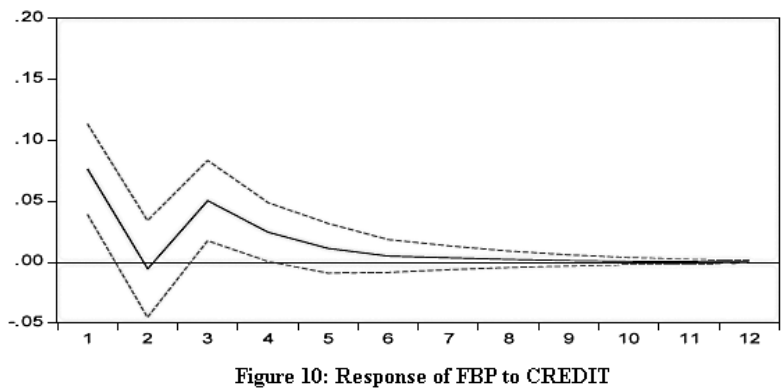



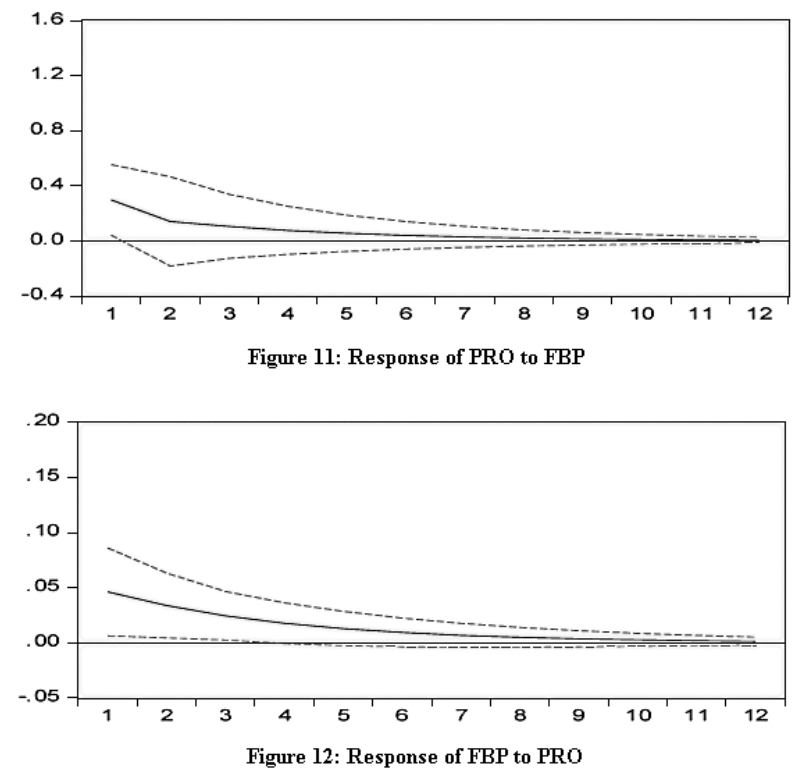

Figures 7-12. Response to generalised One S.D. Innovations \pm 2 S.E.

(The models without the control variables)

In the second model, the effect of a positive shock in FBP is significantly positive for CREDIT at the $1^{\text {st }}$ and $3^{\text {rd }}$ quarter periods, suggesting that the available domestic credit in the market has a positive impact on the FBP, but just for the short run. The initial reverse response is significant and positive in Figure 3, implying that the foreign banks are important for domestic credit in the short run in Turkey. Therefore, rising foreign bank assets in the banking sector are associated with higher credit availability to the domestic market. ${ }^{10}$ This is consistent with the findings of Goldberg et al. (2000) and Clarke (2006). On the other hand, the figure also shows that the effect of shocks disappears in the $3^{\text {rd }}$ quarter. This result in the second model is in line with the model without the control variables.

In terms of profitability in the banking sector, the findings are quite interesting; Figure 6 shows that the response of FBP to one standard deviation shock in PRO is initially positive, but not statistically significant, although it is significant in the model without the control variables. The response is significant and

Apart from actual foreign credit to the domestic market, rising foreign bank penetration in a host country might also force domestic banks to increase domestic credit in order to be competitive against the foreign banks. 

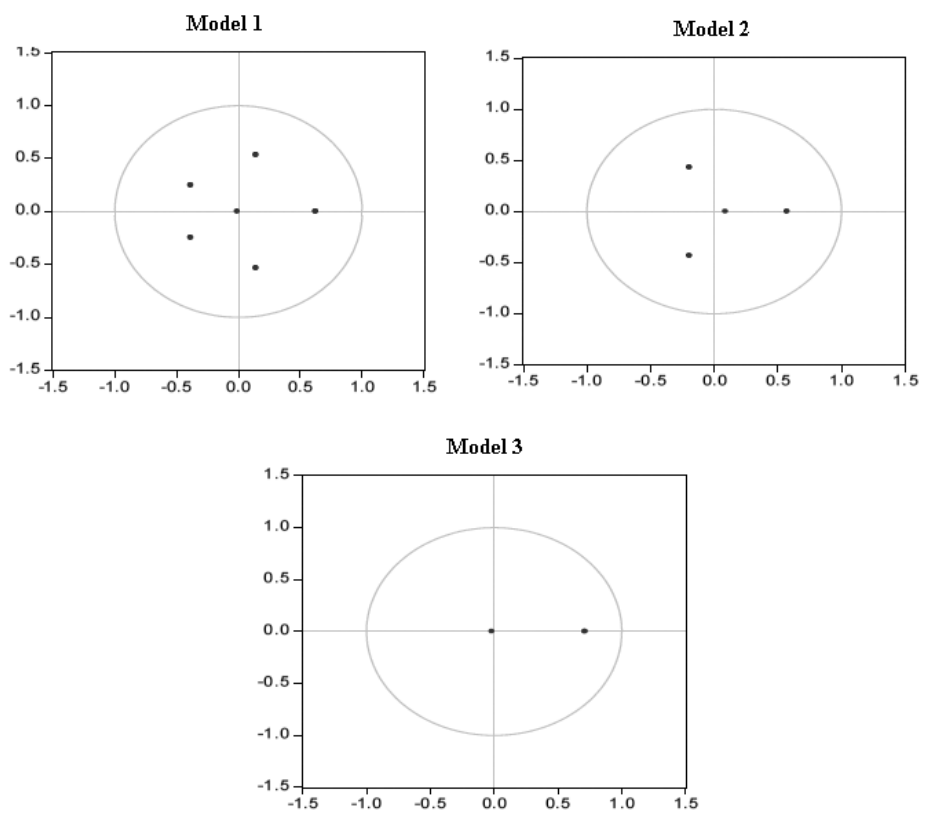

Figure 13. The models with the control variables

positive at the $3^{\text {rd }}$ quarter. The result is not consistent with the existing literature because Denizer (2000), Claessens et al. (2001), Zajc (2004) conclude that rising foreign assets in the banking sector tend to reduce host banking profitability. However, in Turkey, rising foreign bank assets are not mostly associated with higher numbers of banks in the banking sector, especially during the last two decades. 20 foreign banks were running business in Turkey at the end of 1992, and the total assets of these banks in the banking sector was US\$ 2.37 billion. However, the total asset of these banks jumped to US\$ 75.09 billion at the end of 2009 , even though the number of foreign banks in Turkey declined to 17. These numbers indicate that although there was a substantial jump in foreign bank assets. The number of foreign banks also declined. Moreover, the total number of banks also declined from 69 in 1992 to 62 in 2009. Therefore, rising foreign assets in the banking sector was not associated with higher competition. Therefore, it is clear that rising foreign assets are likely to increase profitability due to declining competition in the banking sector. The reverse effect is not statistically significant at the $1^{\text {st }}$ quarter.

The result of variance decomposition in the case of model 1 shows that shock to FBP is influenced by DB (14.475\%) during the twelve-quarter period. On the other hand, DB appears as being more independent and the shock to DB thus 
Table 4. Variance decomposition

\begin{tabular}{|c|c|c|c|c|c|}
\hline \multicolumn{6}{|c|}{ Models with the control variables } \\
\hline \multicolumn{6}{|c|}{ Model 1} \\
\hline \multicolumn{3}{|c|}{ Variance decomposition of DB } & \multicolumn{3}{|c|}{ Variance decomposition of FBP } \\
\hline Period & DB & FBP & Period & DB & FBP \\
\hline 1 & 56.225 & 7.675 & 1 & 11.055 & 80.982 \\
\hline 6 & 54.130 & 8.478 & 6 & 14.482 & 76.861 \\
\hline 12 & 54.087 & 8.471 & 12 & 14.475 & 76.819 \\
\hline \multicolumn{6}{|c|}{ Model 2} \\
\hline \multicolumn{3}{|c|}{ Variance decomposition of CREDIT } & \multicolumn{3}{|c|}{ Variance decomposition of FBP } \\
\hline Period & CREDIT & FBP & Period & CREDIT & FBP \\
\hline 1 & 69.668 & 17.698 & 1 & 11.538 & 81.033 \\
\hline 6 & 44.083 & 18.104 & 6 & 16.553 & 65.257 \\
\hline 12 & 42.944 & 17.669 & 12 & 16.484 & 64.734 \\
\hline \multicolumn{6}{|c|}{ Model 3} \\
\hline \multicolumn{3}{|c|}{ Variance decomposition of PRO } & \multicolumn{3}{|c|}{ Variance decomposition of FBP } \\
\hline Period & PRO & FBP & Period & PRO & FBP \\
\hline 1 & 93.638 & 3.590 & 1 & 3.234 & 84.359 \\
\hline 6 & 93.434 & 2.225 & 6 & 11.846 & 74.656 \\
\hline 12 & 92.799 & 2.346 & 12 & 12.177 & 75.050 \\
\hline \multicolumn{6}{|c|}{ Models without the control variables } \\
\hline \multicolumn{6}{|c|}{ Model 1} \\
\hline \multicolumn{3}{|c|}{ Variance decomposition of DB } & \multicolumn{3}{|c|}{ Variance decomposition of FBP } \\
\hline Period & DB & FBP & Period & DB & FBP \\
\hline 1 & 100.000 & 0.00 & 1 & 15.162 & 84.837 \\
\hline 6 & 97.855 & 2.144 & 6 & 34.020 & 65.979 \\
\hline 12 & 97.845 & 2.154 & 12 & 34.077 & 65.922 \\
\hline \multicolumn{6}{|c|}{ Model 2} \\
\hline \multicolumn{3}{|c|}{ Variance decomposition of CREDIT } & \multicolumn{3}{|c|}{ Variance decomposition of FBP } \\
\hline Period & CREDIT & FBP & Period & CREDIT & FBP \\
\hline 1 & 100.000 & 0.000 & 1 & 19.582 & 80.417 \\
\hline 6 & 93.691 & 6.308 & 6 & 33.366 & 66.633 \\
\hline 12 & 93.690 & 6.309 & 12 & 33.432 & 66.567 \\
\hline \multicolumn{6}{|c|}{ Model 3} \\
\hline \multicolumn{3}{|c|}{ Variance decomposition of PRO } & \multicolumn{3}{|c|}{ Variance decomposition of FBP } \\
\hline Period & PRO & FBP & Period & PRO & FBP \\
\hline 1 & 90.952 & 9.047 & 1 & 0.000 & 100.000 \\
\hline 6 & 93.637 & 6.362 & 6 & 5.241 & 94.758 \\
\hline 12 & 93.682 & 6.317 & 12 & 5.405 & 94.594 \\
\hline
\end{tabular}

Note: Cholesky Ordering: FBP DB CREDIT PRO. Since the aim of this paper is to investigate the relationship between FBP and banking variables (namely DB, CREDIT and PRO), the possible impacts of control variables on the banking variables and FBP and the reverse impacts are not presented in Table 4.

Standard Errors: Monte Carlo (1,000 repetitions). 
Table 5. VAR residual autocorrelation LM tests

\begin{tabular}{lcccccc}
\hline \multicolumn{5}{c}{ Null hypothesis: No serial correlation at lag order h } \\
Model 1 & \multicolumn{3}{c}{ Model 2 } & \multicolumn{2}{c}{ Model 3 } \\
Lags & LM-Stat & Prob & LM-Stat & Prob & LM-Stat & Prob \\
\hline 1 & 2.964 & 0.563 & 2.157 & 0.706 & 7.212 & 0.125 \\
2 & 0.789 & 0.939 & 0.846 & 0.932 & 2.056 & 0.725 \\
3 & 1.563 & 0.815 & 2.113 & 0.714 & 4.104 & 0.392 \\
4 & 2.053 & 0.725 & 1.328 & 0.856 & 8.032 & 0.090 \\
5 & 0.198 & 0.995 & 3.790 & 0.435 & 6.240 & 0.181 \\
6 & 2.576 & 0.631 & 3.526 & 0.473 & 4.223 & 0.376 \\
7 & 4.268 & 0.370 & 4.683 & 0.321 & 1.157 & 0.885 \\
8 & 7.866 & 0.096 & 4.446 & 0.348 & 6.272 & 0.179 \\
9 & 4.066 & 0.397 & 2.902 & 0.574 & 2.232 & 0.693 \\
10 & 1.195 & 0.878 & 0.330 & 0.987 & 5.503 & 0.239 \\
11 & 0.051 & 0.999 & 3.980 & 0.408 & 0.466 & 0.976 \\
12 & 0.645 & 0.957 & 0.401 & 0.982 & 1.298 & 0.861 \\
\hline
\end{tabular}

Note: Probs from chi-square with $4 \mathrm{df}$.

Table 6. VAR residual heteroskedasticity tests

No cross terms (only levels and squares)

\begin{tabular}{cccccc}
\hline \multicolumn{2}{c}{ Model 1 } & \multicolumn{2}{c}{ Model 2 } & \multicolumn{2}{c}{ Model 3 } \\
Chi-sq & Prob & Chi-sq & Prob & Chi-sq & Prob \\
35.218 & 0.505 & 30.358 & 0.173 & 7.572 & 0.817 \\
\multicolumn{7}{c}{ Includes cross terms } \\
\hline \multicolumn{2}{c}{ Model 1 } & \multicolumn{2}{c}{ Model 2 } & \multicolumn{2}{c}{ Model 3 } \\
Chi-sq & Prob & Chi-sq & Prob & Chi-sq & Prob \\
74.584 & 0.679 & 56.644 & 0.065 & 9.551 & 0.847 \\
\hline
\end{tabular}

only accounts for $8.471 \%$ of variation in FBP after controlling for GDP and the 2001 financial crisis. Regarding variance decomposition in the second model, where the shock to CREDIT accounted for $17.669 \%$ of variation in FBP, the shock to FBP is explained by CREDIT (16.484\%) at the end of the twelve-quarter period after controlling for GDP and the 2001 financial crisis. For the banking profitability, the contribution of FBP to PRO variability ranges between $2.225 \%$ and $3.590 \%$ throughout the twelve-quarter period. With respect to PRO, FBP accounts for $3.234 \%$ and $12.177 \%$ of its future variability. ${ }^{11}$

11 As expected and seen in Table 4, the results without the control variables are partially different than the ones with the control variables. However, the main explanations are based on the results from variance decomposition techniques (the models with the control variables). 
As a part of the diagnostic tests, I applied the diagnostic tests for the models with the control variables such as autocorrelation LM and VAR residual heteroskedasticity to test the stability of the VAR models. My evidence, presented in Tables 5 and 6 in the Appendix, show that there is no heteroskedasticity, no autocorrelation, and no serial correlation in my models. In addition, the inverse roots of AR characteristic polynomial were performed to detect the stability of the VAR models; the results of this test are presented in Figure 13. The findings in Figure 13 are found to be satisfactory for all models. As a part of diagnostic test, I also performed the out-of-sample test to see the stable of the models. I performed the same models using first 60 and 56 observations. The results of the models in first 60 and 56 observation models are similar with the models that I performed with 64 observations. There is no change in the significance of causalities and no change in the signs of relationship in impulse response functions. ${ }^{12}$

\section{CONCLUSION}

Until the beginning of the 2000s, FBP did not really take place as expected because of political and macroeconomic instability and bureaucratic barriers for foreign projects. Therefore, the share of foreign bank assets in the Turkish banking sector still remains below 5\%. However, positive macroeconomic indicators, the attainment of political stability, the acceleration of reforms, especially in the finance sector (such as a switch to a floating exchange rate, greater central bank independence, and pursuit of a more credible monetary policy), the foundation of the Coordination Council and Investment Advisory Council, the new FDI law (No.4785), and the reduction in corporate tax led to a high growth rate in the banking sector in Turkey. Apart from these factors, the ongoing negotiation between the EU and Turkey on integration and the gradual rise of the share of banking assets to GNP have made Turkey a more interesting country to investigate and opened new debate on the Turkish banking sector.

Using VAR techniques, this study examines the short-run relations between FBP and the determinants of bank performance, namely domestic bank assets, profitability and total domestic credit, while controlling for GDP and the 2001 financial crisis. In the first model, I find that there is unilateral causality which runs from DB to FBP at the $10 \%$ level. Moreover, response to initial shock to

12 The findings with 60 and 56 observations models are not presented. The models are performed with the control variables. The diagnostic tests implemented for the models with the control variables are also implemented for the models without the control variables. However, the results from the diagnostic tests are not presented for the models without the control variables. 
FBP by DB is significantly positive. Therefore, rising domestic bank assets in Turkey tend to contribute positively to FBP. The reverse line is initially positive and significant as well. Such results in the reverse line are in line with the finding of Engwall et al. (2001). However, they investigated only a one-way impact - from foreign bank assets to domestic bank assets in the Nordic countries. In addition, my finding also reveals that domestic bank assets in model 1 appear more exogenous than foreign bank assets. As a result of the first model, the current government in Turkey should continue to encourage foreign bank entries to force domestic banks to be innovative and to increase their assets.

The result regarding the block exogeneity Wald test also indicates for the second model that there is bilateral causality between FBP and CREDIT. By analysing the impulse response function, FBP is important for credit availability in Turkey in the short run. This is consistent with the finding of Clarke (2006). The reverse line is positive and significant at the $1^{\text {st }}$ and $3^{\text {rd }}$ quarter periods, suggesting that available domestic credit in the market has a positive impact on FBP. This direction of a positive impact is also consistent with the existing literature and rational because it is well known that financial development is an important factor for attracting foreign banks to host markets. As a result of this finding, the current government in Turkey should continue to encourage foreign bank entries in order to increase the availability of credits to the domestic market.

Regarding the relationship between profitability in the banking sector and FBP, my findings are quite interesting. The Granger causality test showed that no causal relationship between FBP and PRO was detected at the 5\% and 10\% levels. More interestingly, the response of PRO to one standard deviation shock in FBP is statistically significant and positive at the $3^{\text {rd }}$ quarter. This implies that rising FBP is associated with rising profitability in the Turkish banking sector. This is because the entry mode of the foreign banks has shifted from greenfield investment to mergers and acquisitions, especially during and after the 2001 financial crisis. ${ }^{13}$ Therefore, substantially rising foreign bank assets have not been associated with an increasing number of foreign banks. This is not in line with previous findings such as Denizer (2000); Claessens et al. (2001) and Zajc (2004). Our finding is likely to open new debates regarding the relationship between foreign bank entries and profitability in developing countries such as Turkey and further research should therefore be made. The reverse effect is initially positive, but not significant, although earlier findings reveal that profitability in a host market is a main driving factor behind the foreign bank entries.

13 The changing perspective of multinational banks over time and the acceleration of privatisation implementations (especially for unhealthy banks and public banks) in the Turkish banking sector have led to changes in the entry mode of foreign banks since the beginning of the 2001 financial crisis. 


\section{REFERENCES}

Aysan, A. F. - Ceyhan, S. P. (2008): What Determines the Banking Sector Performance in Globalized Financial Markets? The Case of Turkey. Physica A: Statistical Mechanics and its Applications, 387: 1593-1602.

Bayraktar, N. - Wang, Y. (2004): Foreign Bank Entry, Performance of Domestic Banks and the Sequence of Financial Liberalization. China Journal of Finance, 2(2): 1-39.

Boni, J. P. - Hasan, I. - Wachtel, P. (2005): Bank Performance, Efficiency and Ownership in Transition Countries. Journal of Banking \& Finance, 29(1): 31-53.

Brealey, R. A. - Kaplanis E. C. (1996): The Determination of Foreign Banking Location. Journal of International Money and Finance, 15: 577-597.

Brooks, C. (2002): Introductory Econometrics for Finance. $1^{\text {st }}$ ed., Cambridge: Cambridge University Press.

Buch, C. M. (2000): Why do Banks Go Abroad? Evidence from German Data. Journal of Financial Markets, Instruments and Institutions, 9: 33-67.

Bumin, M. (2007): The Determinants of Foreign Banks Entry to the Turkish Banking Sector. Banks and Bank Systems, 2(4): 84-92.

Claessens, S. - Demirguc-Kunt, A. - Huizinga, H. (2001): How does Foreign Entry Affect Domestic Banking Markets? Journal of Banking and Finance, 25(5): 891-911.

Clarke, G. R. G. - Cull, R. - Martinez, P. M. S. (2006): Foreign Bank Participation and Access to Credit across Firms in Developing Countries. Journal of Comparative Economics, 34(4): 774-795.

Cochrane, J. H. (1991): A Critique of the Application of Unit Root Tests. Journal of Economic Dynamics and Control, 15(2): 275-284.

Cull, R. - Peria, M. S. M. (2010): Foreign Bank Participation in Developing Countries; What do We Know about the Drivers and Consequences of This Phenomenon? Policy Research Working Paper, No. 5398.

DeJong, D. N. - Nankervis, J. C. - Savin, N. E. - Whiteman, C. H. (1992): The Power Problem of Unit Root Tests in Time Series with Autoregressive Errors. Journal of Econometrics, 53(1-3): 323-343.

Demir, N. - Mahmud, S. F. - Babuscu, S. (2005): The Technical Inefficiency Effects of Turkish Banks After Financial Liberalization. The Developing Economies, 48: 396-411.

Demirguc-Kunt, A. - Huizinga, H. (1999): Determinants of Commercial Bank Interest Margins and Profitability: Some International Evidence. World Bank Economic Review, 13(2): 379-408.

Demirguc-Kunt, A. - Levine, R. - Min, H. G. (1998): Opening to Foreign Banks: Issues of Stability, Efficiency, and Growth. Proceedings of the Bank of Korea Conference on the Implications of Globalization of World Financial Markets, Korea, December 1998.

Denizer, C. (1998): Foreign Entry in Turkey's Banking Sector: 1980-1997. Mimeo, World Bank.

Denizer, C. - Dinc, M. - Tarimcilar, M. (2007): Financial Liberalization and Banking Efficiency: Evidence from Turkey. Journal of Productivity Analysis, 27(3): 177-195.

Denizer, C. A. (2000): Foreign Entry in Turkey's Banking Sector: 1980-97. The World Bank Working Paper, No. 2462.

Detragiache, E. - Gupta, P. (2008): Foreign Banks in Poor Countries: Theory and Evidence. Journal of Finance, 63(5): 2123-2160.

Dickey, D. A. - Fuller, W. (1979): Distribution of the Estimators for Autoregressive Time Series with a Unit Root. Journal of American Statistical Association, 74: 427-431.

Elliott, G. - Rothenberg, T. - Stock, J. H. (1996): Efficient Tests for an Autoregressive Unit Root. Econometrica, 64(4): 813-836. 
Engwall, L. - Marquardt, R. - Pedersen, T. - Tschoegl, A. E. (2001): Foreign Bank Penetration of Newly Opened Markets in the Nordic Countries. Journal of International Financial Markets, 11(1): 53-63.

Focarelli, D. - Pozzolo, A. F. (2005): Where do Banks Expand Abroad? An Empirical Analysis. Journal of Business, 78(6): 2435-2464.

Goldberg, L. - Dages, B. G. - Kinney, D. (2000): Foreign and Domestic Bank Participation in Emerging Markets: Lessons from Mexico and Argentina. NBER Working Paper, No. 7714.

Goldberg, L. G. - Grosse, R. (1992): Location Choice of Foreign Banks in the United States. Journal of Economics and Business, 46(5): 367-379.

Granger, C. W. J. (1969): Investigating Causal Relations by Econometric Models and Cross-Spectral Methods. Econometrica, 37(3): 424-438.

Granger, C. W. J. (1988): Some Recent Developments in a Concept of Causality. Journal of Econometrics, 39(1-2): 199-211.

Haas, R. T. A. d. - Lelyveld, I. P. P. v. (2004): Foreign Bank Penetration and Private Sector Credit in Central and Eastern Europe. Journal of Emerging Market Finance, 3(2): 125-151.

Hill, R. C. - Grifiths, W. E. - Lim, G. C. (2008): Principles of Econometrics. $3^{\text {rd }}$ ed., New York: John Wiley \& Sons.

Isik, I. - Hassan, M. K. (2002): Technical, Scale and Allocative Efficiencies of Turkish Banking Industry. Journal of Banking and Finance, 26: 719-766.

Kamil, H. - Rai, K. (2009): The Global Credit Crunch and Foreign Banks' Lending to Emerging Markets: Why did Latin America Fare Better? International Monetary Fund Working Paper, No. /10/102.

Knickerbocker, F. T. (1973): Oligopolistic Reaction and Multinational Enterprise. $1^{\text {st }}$ ed., Boston: Harvard University Press.

Koop, G. - Pesaran, M. H. - Potter, S. (1996): Impulse Response Analysis in Nonlinear Multivariate Models. Journal of Econometrics, 74(1):119-147.

Lensink, R. - Hermes, N. (2004): The Short-Term Effects of Foreign Bank Entry on Domestic Bank Behaviour: Does Economic Development Matter? Journal of Banking and Finance, 28(3): $553-$ 568.

Lin, X. - Zhang, Y. (2009): Bank Ownership Reform and Bank Performance in China. Journal of Banking \& Finance, 33(1): 20-29.

Matousek, R. - Fukuyama, H. (2011): Efficiency of Turkish Banking: Two-stage System Variable Returns to Scale Model. Journal of International Financial Markets, Institutions \& Money, 21(1): 71-91.

Morgan, D. P. - Strahan, P. E. (2003): Foreign Bank Entry and Business Volatility: Evidence from U.S. States and Other Countries. NBER Working Paper, No. 9710.

Ng, S. - Perron, P. (2001): Lag Selection and the Construction of Unit Root Tests with Good Size and Power. Econometrica, 69(6): 1519-1554.

Ng, S. - Perron, P. (2005): A Note on the Selection of Time Series Models. Oxford Bulletin of Economics and Statistics, 67(1): 115-134.

Ocal, T. (1992): Turk Banka Sistemi. $1^{\text {st }}$ ed., Ankara: Ankara Iktisadi ve Ticari Ilimler Akademisi Yayinlari.

Satta, T. A. (2004): The Influence of Foreign Bank Entry on Lending to Small Firms in Tanzania. The Journal of Policy Reform, 7(3): 165-173.

Sims, C. A. (1980): Macroeconomics and Reality. Econometrica, 48(1):1-48.

Temel Nalin, H. (2013): Determinants of Household Saving and Portfolio Choice Behaviour in Turkey. Acta Oeconomica, 63(3): 309-332. 
Yamori, N. (1998): A Note on the Location Choice of Multinational Banks: The Case of Japanese Financial Institutions. Journal of Banking and Finance, 22: 109-120.

Yeldan, A. E. (1997): Financial Liberalization and Fiscal Repression in Turkey: Policy Analysis in a CGE Model with Financial Markets. Journal of Policy Modelling, 19(1):79-117.

Yildirim, C. (2002): Evolution of Banking Efficiency within an Unstable Macroeconomic Environment: The Case of Turkish Commercial Banks. Applied Economics, 34(18): 2289-2301.

Zajc, P. (2004): The Effect of Foreign Bank Entry on Domestic Banks in Central and Eastern Europe. In: Balling, M. - Lierman, F. - Mulllineux, A. (eds): Financial Markets in Central and Eastern Europe: Stabilty and Efficiency Perspectives. London - New York: Routledge.

Zivot, E. - Wang, J. (2005): Modelling Financial Time Series with S-PLUS. New York: Springer. 